\title{
Editorial
}

\section{Higher Education in Innovation Ecosystems}

\author{
Yuzhuo Cai ${ }^{1} \mathbb{C}$, Jinyuan $\mathrm{Ma}^{2, *} \mathbb{C}$ and Qiongqiong Chen ${ }^{3}$ \\ 1 Faculty of Management and Business, Tampere University, 33014 Tampere, Finland; yuzhuo.cai@tuni.fi \\ 2 Centre for Higher Education Research, Southern University of Science and Technology, \\ Shenzhen 518055, China \\ 3 Office of Strategic Planning and Development, Southern University of Science and Technology, \\ Shenzhen 518055, China; chenqq@sustech.edu.cn \\ * Correspondence: majy@sustech.edu.cn
}

Received: 6 May 2020; Accepted: 20 May 2020; Published: 27 May 2020

check for updates

\begin{abstract}
While higher education has been considered as both an 'engine' for innovation and a 'catalyst' for sustainability development, the integration of both the 'innovation engine' and 'sustainability catalyst' roles is best reflected in higher education's engagement in innovation ecosystems-the theme of this special issue, including 16 articles dealing with the topic from various perspectives. In this editorial, we outline an overarching framework about the relations between higher education and innovation ecosystem. When elaborating the framework, we provide a new definition of innovation ecosystem and identify three roles of university in innovation ecosystems, based on synthesizing relevant literature. The framework could facilitate readers to comprehend each of the collected articles and find synergy among them.
\end{abstract}

Keywords: higher education; university; sustainability; innovation ecosystem; third mission; knowledge-based society; global innovation networks

\section{Introduction}

The policy and research discussions on sustainable development often deal with two intricately interrelated transformations, namely societal transformation (or innovation in the society) and university transformation (or innovation in the university) [1]. Contemporary societal changes have been recently described as a transformation from knowledge society 1.0 to knowledge society 2.0 [2] that fosters an innovation ecosystem [3]. The core underlying the knowledge society 2.0 is that knowledge is not simply distinguished between tacit and codified type as in knowledge economy 1.0 but context-dependent. Consequently, learning and knowledge production is now taking place in the context of social interactions rather than in organizational contexts [4,5]. Its implication on an innovation ecosystem is that the core elements in the system are increasingly interdependent and bind together by co-evolution/co-creation mechanisms, comparable to complicated relations among organisms in a bio-system [6].

In the innovation ecosystem, a university is not merely serving as a primary engine for economic growth through knowledge transfer [7], but is required to be more socially responsible [8]. As put by UNESCO's Chief of Higher Education Sector, Peter J. Wells, "Perhaps never before in recent history has the role of higher education been so intricately tied to the economic, social and environmental fabric of the modern world" [9]. The societal changes demanding broader roles of universities also calls for, and leads to, substantial changes within the internal fabric of the university. The innovations in both the society and universities call for our renewed understanding of higher education in society, which becomes a new research agenda in studies on innovation in higher education [1].

This special issue is a timely response to the new research agenda with 16 selected articles, making theoretical, methodological, or empirical contributions to the emerging research agenda on higher 
education in innovation ecosystems. While the special issue primarily targets academic readers, it is also of relevance to policy and managerial audiences. To help readers better understand each article and find synergy among the articles, we provide here an overarching framework, in which some key concepts are defined and the changing relations between higher education and innovation ecosystem are elaborated.

\section{Conceptualizing Innovation Ecosystem}

The notion of innovation ecosystem has been evolved from the concept of business ecosystem, which was originally proposed by Moore in 1993 [10], who proposed a perspective of seeing a company as part of a business ecosystem instead of a single industry. The ecosystem crosses a variety of industries; "In a business ecosystem, companies co-evolve capabilities around a new innovation: they work cooperatively and competitively to support new products, satisfy customer needs, and eventually incorporate the next round of innovations" (p. 76) [10]. The term business ecosystem has often been treated exchangeable to innovation ecosystem [11-13]. Besides, another similar concept to business ecosystem is knowledge ecosystem [14]. Valkokari [15] identifies the differences between the three kinds of ecosystems: business ecosystem focuses on creating customer value; knowledge ecosystem focuses on generating new knowledge and technologies; innovation ecosystem integrates exploration (knowledge) and exploitation (business) ecosystems.

However, such distinction does not clearly distinguish innovation ecosystem from the innovation system [16-19], which consists of complex functions and interactions among various organizational actors, involved in processes of both knowledge exploration and knowledge exploitation, and their institutional contexts, in the forms of governmental policies and social norms [20]. As noted by Oh, Phillips, Park and Lee [6] there are, "few academic articles using 'innovation ecosystem' in a manner that would distinguish an innovation ecosystem from an innovation system" (p. 2).

What makes the concept innovation ecosystem distinct to either business ecosystem or innovation ecosystem is value co-creation $[3,21]$. "The concept of value co-creation is basically associated with a business strategy focusing on interactive relationships between producers and consumers" (p. 5247) [21]. The business ecosystem is primarily concerned with value capture and innovation ecosystem is more related to value co-creation [3]. "Ecosystems can't be deliberately established as system-like organizations ... Ecosystems are tailored to interactive co-creation of values, while systems are not" (p. 5248) [21]. Carayannis, et al. [22] take a broad perspective to understand the value co-creation, that is not merely between producers and customers but takes places among multiple actors in the framework of Quadruple Helix.

Synthesizing the discussions on the new features of innovation ecosystem, Cai, et al. [23] claim that "what is new in the innovation ecosystem is its ecological aspect, characterized by the interdependency among different collaborative actors and the co-evolution/co-creation that binds them together over time, along with the sustainable development dimension" (p. 6) [23]. They also refer to "co-innovation" [24] networks when understanding innovation ecosystem. The concept of co-innovation includes "collaboration, coordination, co-creation, convergence, and complementary" (p. 361) [25], and it can be understood as "the dynamically intertwined processes of co-opetition, co-evolution, and co-specialization within and across regional and sectoral innovation ecosystems" (p. 153) [22]. When understanding the mechanisms in the innovation ecosystems, Cai et al. call for integrating the insights of Helix models of innovation [23], including the Triple Helix Model [7,26], Quadruple Helix Model [27], and Triple Helix of sustainability [28].

In such light, we define innovation ecosystem as co-innovation networks, in which actors from organizations concerned with the functions of knowledge production, wealth creation and norm control interact with each other in forming co-evolution and interdependent relations (both direct or indirect) in cross-geographical contexts, and, through which new ideas and approaches from various internal and external sources are integrated into a platform to generate shared values for the sustainable transformation of the society. Compared to most commonly cited definitions of innovation 
ecosystem [3,29], our definition highlights three new aspects of interactions in co-innovation networks, namely cross-sectoral, transnational and indirect, drawing insights from the literature of innovation, geography, and biology studies.

First, the actors in an innovation ecosystem are from different sectors. Such a view is clearly reflected in the conceptualization of both Triple Helix [30] and Quadruple Helix [27] models of innovation. While most studies on innovation ecosystems mainly focus on companies and industrial clusters [3], it should be noted that in the knowledge-based society, innovation is fostered by the interactions of organizations with multiple functions, such as wealth generation, knowledge production, and normative control [7,26]. When elucidating the Quadruple Helix model, Carayannis and Campbell [27] consider that in an innovation ecosystem, "people, culture and technology - forming the essential 'Mode 3 Innovation Ecosystem' building block meet and interact to catalyze creativity, trigger invention and accelerate innovation across scientific and technological disciplines, public and private sectors (government, university, industry and non-governmental knowledge production, utilization and renewal entities) and in a top-down, policy-driven as well as bottom-up, entrepreneurship-empowered fashion" (pp. 202-203).

Second, the actors from different geographical locations can be interlinked in an innovation ecosystem. This has been clearly noted by Sotarauta, et al. [31] when identifying key features of innovation ecosystems, using the label "multi-locational", meaning that knowledge flows and innovation processes take place in multiple geographical locations (pp. 31-32). The transnational dimension of innovation ecosystems has also been reflected in innovation research [32-36] and geography studies [37], both addressing the direction of innovation systems becoming global or transnational.

Third, when studying the relations in the innovation ecosystem, it is crucial to pay attention to indirect or unobvious relations as suggested by Cai, Ferrer and Lastra [23]. This also corroborates the approaches to the ecosystem in the biological world. As Krivtsov [38] noted, ecological research on ecosystems had mainly concentrated on investigations of direct relationships, whilst examining indirect relations and interdependences (especially the less obvious relations) between organisms was a recent phenomenon. The "organic nature" of innovation ecosystem means that the system evolves through its components' continuous adaptation to changing situations [31].

In spite of our attempt to providing a definition of innovation ecosystem, we admit that any definitions are not sufficient to fully understand the system. Rather, a conceptual or theoretical framework for elucidating the nature and dynamics of innovation ecosystems is needed. As argued by Oh, Phillips, Park and Lee [6], the concept of innovation ecosystem is a high level of abstraction and loosely used; it is often understood as a metaphor rather than a theory or framework. Thus, Ritala and Almpanopoulou [39] call for future research to improve the conceptual, theoretical and empirical rigor of the notion of innovation ecosystem. One barrier to advancing the conceptualization of innovation ecosystem lies in the narrow focus of existing approaches, tending to assemble innovation ecosystem according to the components in a natural ecosystem [40]. Such an approach leads to some seemingly unresolvable paradoxes, such as the deliberate design of innovation ecosystems not actually resembling ecosystems in nature [6,41].

To develop a rigorous conceptualization of innovation ecosystem is a systematic project requiring collaboration among scholars in different fields of research, with multiple disciplinary insights and through solid empirical investigations. For instance, in both higher education and innovation studies, there is a tendency in bringing emerging factors and complex links in the innovation ecosystem into analysis foci $[42,43]$. This Special Issue is aimed to contribute to a potential analytical framework of innovation ecosystem by focusing on the changing roles of universities in innovation ecosystems and related transformations within higher education. 


\section{Changing Roles of Higher Education in Innovation Ecosystems}

While our society is becoming increasingly knowledge-based, the prominent role of universities in societal engagement, especially in the regional context, is becoming a shared understanding $[44,45]$. Most concepts in innovation studies, such as innovation system [19], Triple Helix model [30], and open innovation [46], originated in the context of developing knowledge-based society, stress new kinds of relations between universities and economic development. Etzkowitz [7] clearly states that the university has transformed from a secondary to a primary institution for economic growth in the knowledge-based society. Such "innovation engine" role of higher education emphasizes the long-term economic effects of the university's societal engagement, such as improving the quality of local labor, transferring technology to the industry, and enhancing the attractiveness of the local environment for entrepreneurs [20]. This is in contrast to the short-term multiplier effects mainly through universities' employing local workers, occupying a large area of land and their demand for local services [47].

As we are entering the era of innovation ecosystem with distinct features such as sustainable societal transformation, co-innovation and transnational knowledge exchange, there are also new societal demands for the higher education. What are the changing roles of higher education in the context of innovation ecosystems? This is a new research agenda. Nevertheless, some recent studies may shed light on it. For instance, a recent report published by the European University Association (EUA) specified four roles of universities in regional innovation systems as follows [42]: "Education: providing human 'capital' for innovation", "Research: knowledge (co-)production for private and public value creation", "Knowledge exchange for innovation systems: From technology transfer to multi-actor co-creation" and "Strategic transformation: embedding innovation" (pp. 22-47). Continuing from Cai's call for the concept of socially responsible entrepreneurial university [48], Cai, Ferrer and Lastra [23] suggest three roles of university in transnational university-industry co-innovation networks in innovation ecosystems, namely transnational technology transfer, trust-building between the university and industrial actors, and fostering changes of social norms needed in building innovation ecosystems. While the EUA's report is focusing on university's regional engagement [42], Cai, Ferrer and Lastra [23] understand the role of universities in a global context. However, Cai, Ferrer and Lastra [23] do not discuss the roles in details. Here, we will further elaborate on the three roles of university in innovation ecosystems proposed by Cai, Ferrer and Lastra [23] by synthesizing relevant literature.

First, the role of university is changing from being a central player in technology transfer to being an anchor organization in knowledge exchange. Technology transfer is typically defined as "the process of moving technology from an institution of the science base (e.g., a higher education institution) to an industrial organization, which ... commercializes the technology through the implementation of new processes, the development and launch of new products or the facilitation of a successful and innovative organizational change" (p. 613) [49]. While technology transfer is one direction move of the knowledge from the academy to the industry, "knowledge exchange", as described by Moreton [50], is bi-directional. "[U]niversity-industry interaction does not involve only transferring knowledge from the former to the latter; it also helps academics to develop interesting research questions, conduct better research and provide improved understanding of research applications in industry" (p. 109) [51]. Knowledge exchange entails both aspects of collective learning between organizations from different sectors and (conventional) technology transfer [5]. Such bi-directional nature of knowledge exchange is the key to value co-creation. Here, the university is not merely a knowledge creator but also an enabler of value co-creation.

Second, the university is taking a new role for trust-building between actors in innovation ecosystems. The interactions among actors in an innovation ecosystem can be understood as social relations and the knowledge exchange is an outcome of social relations. Social relations/interactions can be explained by two theories, namely social exchange theory [52] and social network theory [53], which are supplementing to each other [54]. From both perspectives, trust is considered a key factor to successful knowledge exchange and co-innovation. 
According to social exchange theory, social interactions are shaped by the reciprocal exchange of rewards (or more rewards than costs) [52]. When Muthusamy and White [5] apply social exchange theory to analyze social interactions in the process of collective learning and knowledge transfer, they posit that "[s]ince there is no way to assure an equivalent return for a favor, social exchange requires trusting others to discharge their obligations" (p. 418). As such, successful interactions between actors in an innovation ecosystem relies on trust between the collaborators [55].

From the perspective of social network theory, innovation requires a combination of both strong and weak ties [56-58]. "Weak ties aid exploration (the generation of new ideas), whereas strong ties aid exploitation (the implementation of new ideas)" (p. 212) [59]. The creation and diffusion of innovation are mostly attributed to weak ties [60]. While the most useful knowledge/ideas would come from weak ties, one challenge is that the level of trust between actors connected by weak ties might be low [61]. Due to its own trustworthy status in the society and its close links to actors across sectors via alumina and research partnership, university can be a unique social trust builder [23,62] for co-innovation networks.

Third, the university is not merely an entrepreneurial university but also an institutional entrepreneur in the innovation ecosystem [63]. Institutional entrepreneurs are those organizational or individual actors who not only initiate diverse changes in the institutional environment but also actively participate in the implementation of such changes [64]. "Institutions can be generally understood as social orders [65], social rules [66], or taken-for-granted norms and beliefs [67], which are seen by actors as natural, rightful, expected, and legitimate" (p. 462) [68]. Audretsch [69] asserts that "while the entrepreneurial university was a response to generating technology transfer and knowledge-based start-ups, the role of the university in the entrepreneurial society has broadened to focus on enhancing entrepreneurship capital and facilitating behavior to prosper in an entrepreneurial society" (p. 312). Both "enhancing entrepreneurship" and "facilitating behavior" requires changes in the institutional environment. The process of fostering institutional changes can be understood as social entrepreneurship [70], which is "an innovative approach to achieve social mission" (p. 744) [71], being considered as a key to an innovation system [72].

The three emerging roles all indicate that universities are becoming the catalyst for sustainable development in innovation ecosystems. Knowledge exchange is crucial for suitability [73]; trust is the foundation of the sustainable networks [74]; social entrepreneurship is indispensable to sustainable social change [75].

The articles collected in this Special Issue, to varying extents, reflect the changing roles of higher education in innovation ecosystems. Meanwhile, they also report transformations within higher education and universities' responses to both external and internal transformations. When addressing these issues, the studies make both theoretical and methodological contributions in the research on higher education in innovation ecosystems.

\section{The Articles in the Special Issue}

The 16 articles collected in the Special Issue can be generally put in four categories: (1) New demands for universities arising from the transformation in the society towards innovation ecosystems, (2) Transformations within higher education responding to emerging societal demands, (3) Dynamics of the interaction of university with other innovation actors in a transnational context, (4) Academic and student mobility for higher education innovation. Next, we will briefly introduce each article in the Special Issue in the four categories respectively.

\subsection{New Demands for Universities Arising from the Transformation in the Society towards Innovation Ecosystems}

The article by Ye and Wang, "Exploring the Triple Helix Synergy in Chinese National System of Innovation" [76], creates a simulation equation based on non-linear complex systems theory to offer steps towards a possible solution to estimate the Triple Helix synergy in China. The research 
considers that the domestic academic knowledge capacity is the order variable which is dominant in the Triple Helix evolution in China, and the industry plays as the major driving force in China's national innovation system. It also suggests that policies with strong incentives are effective in enhancing the absorptive capacity of industry and knowledge transfer of universities.

The green economy is regarded as an important tool for sustainable development. However, the role of higher education in a green economy is seldom discussed in the literature. The article, "An Empirical Study of the Role of Higher Education in Building a Green Economy" by Gao, Ding, Chen and Min [77] contributes to filling this gap by proposing a interpretation of the influencing mechanism of higher education on the green economy. They find that higher education plays a significant role in building a green economy, and green gross domestic product (GDP) is more responsive to changes in higher education than the traditional GDP.

Considering the increasing trends of higher education involvement in social innovation practices, Kumari, Richa, Kwon, Lee and Choi examine the role of Higher Educational Institutions (HEIs) in promoting, creating, and sustaining social innovation, in their article "Co-Creation for Social Innovation in the Ecosystem Context: The Role of Higher Educational Institutions" [78]. They develop a theoretical understanding of the "co-creation for social innovation" concept and to understand the functions and activities of HEIs that can contribute to this process. They argue that different activities such as mutual learning and knowledge diffusion using a transdisciplinary approach, technology-based learning and collaboration, and relational transformation are key enablers that can promote social innovation.

In the context of knowledge economy, universities are increasingly paying more attention to developing academic entrepreneurship. In the article, "Developing the Entrepreneurial University: Factors of Influence", Bezanilla, García-Olalla, Paños-Castro and Arruti analyze the relationships between the relevant factors that contribute to the development of the entrepreneurial university in Spain through a quantitative inquiry. They find that universities' contextual factors have only minor influence on the development of entrepreneurial university. Factors, such as entrepreneurship funding, training in entrepreneurship for faculty staff, mission and strategy, support from the management team, training and research in entrepreneurship and extra-curricular training, are found as most influential. Their study helps universities to adopt measures that are better suited to promoting entrepreneurship [79].

In response to the new demands of external stakeholders such as knowledge-intensive enterprises, higher education institutions have to play the role of knowledge brokers in smart specialization. The study by Kangas and Aarrevaara [80], "Higher Education Institutions as Knowledge Brokers in Smart Specialisation", uses a case of European Commission's smart specialization project and collects data through 20 interviews; it finds out that higher education institutions' role as knowledge brokers can be legitimated from social networking, decision-making and cluster building as well as exchange programs.

\subsection{Transformations within Higher Education Responding to Emerging Societal Demands}

In the article, "Training Entrepreneurial Competencies with Open Innovation Paradigm in Higher Education" [81], Iglesias-Sánchez, Jambrino-Maldonado and de las Heras-Pedrosa use mixed methods combining a qualitative technique based on three focused groups of lecturers, students and entrepreneurs, with a regression analysis seeking connections between entrepreneurial intention and employability with entrepreneurial competences. The study identifies the following teaching methods effective for university students to improve entrepreneurial competencies required by future employers: hackathon, team building, role play, and practical cases with entrepreneurs.

The article by Portuguez Castro, Ross Scheede and Gómez Zermeño on "The Impact of Higher Education on Entrepreneurship and the Innovation Ecosystem: A Case Study in Mexico" [82], presents a case study of a Master of Science program to train Mexican students with entrepreneurial skills. Based on the survey data from the former students of this program, the study concludes that the training 
methods taken by the program are useful competencies for creating technology-based enterprises and can be emulated in Latin America.

The article by Wang, Yang, Cheng and Ni, "Postgraduate Education of Board Members and R\&D Investment-Evidence from China" [83], reveals the correlation between firms' research and development $(R \& D)$ investment with the directors' postgraduate education experience. The research finds out that the percentage of directors with doctorates significantly increases the chance of investing R\&D activities; in the second industry, the higher the proportion of postgraduate education degree holder as directors in a firm, the more expenditure the firm invests in R\&D activities. Yet, there is no such association in the third industry. The findings are generated from taking descriptive statistics, ordinary least square (OLS) regression and instrumental variable (IV) estimation based on a sample of 1374 listed companies in China. This study enriches the innovation management theory, upper echelon theory, and human capital theory.

The complex demands from the society cause tensions in universities. To understand the tensions within universities from the perspective of sustainable development, Lattu and Cai introduce an analytical framework in their article "Tensions in the Sustainability of Higher Education-the Case of Finnish Universities" [84]. The analytical framework is based on the conceptualization of corporate sustainability and adjust it to the context of higher education by using Finnish universities as a testbed for analysis. The authors also identify six tensions relating to the sustainability of Finnish universities.

The article by Cruz-Amarán, Damaris, Maribel Guerrero, and Alma Delia Hernández-Ruiz [85], "Changing Times at Cuban Universities: Looking into the Transition towards a Social, Entrepreneurial and Innovative Organization", interprets a particular case of socialist higher education system in the process of entrepreneurial transition over the past two decades. The study proposes an analytical model by integrating the theoretical bases of entrepreneurial universities, social entrepreneurship, and business innovation model. The case study of Cuban universities finds out that state regulations, the closed-loop from teaching to commercialization, and the creation of hybrid knowledge structure are determinant factors in Cuban universities' transformation from traditional business model to an innovative one.

\subsection{Dynamics of the Interaction of University with Other Innovation Actors in a Transnational Context}

In Cai, Ferrer and Lastra's article on "Building University-Industry Co-Innovation Networks in Transnational Innovation Ecosystems" [23], they open up new horizons in research on the role of universities in innovation systems by bringing the university-industry interactions into transnational contexts and proposing an innovative method of combining theoretical modeling in social sciences research and a specific artificial intelligence technique-machine learning. Their proposed novel approach is particularly for discovering hidden-links in the transnational university-industry co-innovation networks. These hidden-links between university and industry have the potential to be utilized for trust-building and institutional change in transnational innovation ecosystems.

In Ma's article on "Developing Joint R\&D Institutes between Chinese Universities and International Enterprises in China's Innovation System" [86], she uses an empirical case study approach to advance theoretical understandings of the interactions of institutional logics which result in varied patterns of a joint R\&D institute co-established by a Chinese university and international enterprise. Guided by an analytical framework of institutional logics in the evolution of the Triple Helix model $[87,88]$, this study contributes to the research gap of the university's engagement in innovation systems in a transnational context.

\subsection{Academic and Student Mobility for Higher Education Innovation}

The article "Mobility, Knowledge Transfer, and Innovation: An Empirical Study on Returned Chinese Academics at Two Research Universities" by Chen and Li [89] discuss the consequence of academic mobility on higher education innovation through an empirical study on returned Chinese academics at two research universities. They find that returned academics play an important role 
in promoting higher education innovation in China by mobilizing their transnational capital and resources. However, their capacity to innovate is largely subject to their working environment. They suggest that it is important to improve institutions' working conditions and culture in order to harvest the benefits of mobility.

The mobility of innovative resources such as talents, technology, and capital is important for the future of sustainability in higher education. However, we know little about faculty mobility from countries in which the academic profession is undergoing dramatic alterations. In their article, "Does Money Accelerate Faculty Mobility? Survey Findings from 11 Research Universities in China" [90], Liu, Yin, Lyu and Lin examine the motivations for and the outcomes of faculty mobility in the context of China by using survey data from 445 faculty members at 11 major research universities in China. They find a significant relationship between mobility frequency and indirect income. Their study suggests that more successful mechanisms to attract or retain talented scholars should be developed and that these mechanisms should not focus exclusively on income.

The study by Akhtar, Pratt and $\mathrm{Hu}$, "Sustainability of the Belt and Road Initiative: An Integrated, Conceptual Framework for Instructional Communication in China's Universities" [91], develops models of instructional communication and intercultural sensitivity in learner-centered pedagogical context, for the purpose of reducing misunderstandings caused by problematic interactions between international students and Chinese faculties in the classroom. The study acknowledges the asymmetrical discourses or unequal encounters between native and non-native speakers in China's multicultural university classrooms within the context of China's dominant high-context culture. International students need to be more cognizant of the salient features of Chinese culture (e.g., differences in communication habits and in modes of thinking) and the educational system before arriving in China.

Li's study, "How to Retain Global Talent? Economic and Social Integration of Chinese students in Finland" [92], adopts a structure and agency approach to examine the individual and societal factors that affect international students' integration into the host environments. The data were collected through semi-structured interviews with Chinese students in Finland. Recommendations are provided for policymakers, managers of higher education institutions and individual students to advance the economic and social integration of international graduates in non-Anglophone contexts as global talents.

Author Contributions: Conceptualization, Y.C.; original draft preparation, Y.C., J.M. and Q.C.; review and editing, Y.C. and J.M. All authors have read and agreed to the published version of the manuscript.

Funding: This research was funded by the National Education Sciences "Thirteenth Five-Year Plan" of China, National General Projects in 2019, "Research on the Societal Impact and Assessment Mechanism of International (Regional) Scientific Research Cooperation in Chinese Universities", grant number BIA190166.

Acknowledgments: We are grateful for all the authors for their contribution to the Special Issue.

Conflicts of Interest: The authors declare no conflict of interest.

\section{References}

1. Cai, Y. From an analytical framework for understanding the innovation process in higher education to an emerging research field of innovations in higher education. Rev. High. Educ. 2017, 40, 585-616. [CrossRef]

2. Rutten, R.; Boekema, F. From Learning Region to Learning in a Socio-spatial Context. Reg. Stud. 2012, 46, 981-992. [CrossRef]

3. Gomes, L.A.d.V.; Facin, A.L.F.; Salerno, M.S.; Ikenami, R.K. Unpacking the innovation ecosystem construct: Evolution, gaps and trends. Technol. Forecast. Soc. Chang. 2018, 136, 30-48. [CrossRef]

4. Tsoukas, H. A Dialogical Approach to the Creation of New Knowledge in Organizations. Organ. Sci. 2009, 20, 941-957. [CrossRef]

5. Muthusamy, S.K.; White, M.A. Learning and Knowledge Transfer in Strategic Alliances: A Social Exchange View. Organ. Stud. 2005, 26, 415-441. [CrossRef]

6. Oh, D.-S.; Phillips, F.; Park, S.; Lee, E. Innovation ecosystems: A critical examination. Technovation 2016, 54, 1-6. [CrossRef] 
7. Etzkowitz, H. The Triple Helix: University-Industry-Government Innovation in Action; Routledge: New York, NY, USA; London, UK, 2008; p. 164.

8. Sørensen, M.P.; Geschwind, L.; Kekäle, J.; Pinheiro, R. (Eds.) The Responsible University: Exploring the Nordic Context and Beyond; Palgrave Macmillan: Cham, Switzerland, 2019.

9. Wells, P.J. UNESCO'S Introduction: The role of Higher Education Institutions today. In Higher Education in the World 6. Towards a Socially Responsible University: Balancing the Global with the Local; Grau, F.X., Goddard, J., Hall, B.L., Hazelkorn, E., Tandon, R., Eds.; Global University Network for Innovation (GUNi): Barcelona, Spain, 2017.

10. Moore, J.F. Predators and prey: A newecology of competition. Harv. Bus. Rev. 1993, 71, 75-86.

11. Overholm, H. Collectively created opportunities in emerging ecosystems: The case of solar service ventures. Technovation 2015, 39-40, 14-25. [CrossRef]

12. Gómez-Uranga, M.; Miguel, J.C.; Zabala-Iturriagagoitia, J.M. Epigenetic Economic Dynamics: The evolution of big internet business ecosystems, evidence for patents. Technovation 2014, 34, 177-189. [CrossRef]

13. Ritala, P.; Agouridas, V.; Assimakopoulos, D.; Gies, O. Value creation and capture mechanisms in innovation ecosystems: A comparative case study. Int. J. Technol. Manag. 2013, 63, 244-267. [CrossRef]

14. Clarysse, B.; Wright, M.; Bruneel, J.; Mahajan, A. Creating value in ecosystems: Crossing the chasm between knowledge and business ecosystems. Res. Policy 2014, 43, 1164-1176. [CrossRef]

15. Valkokari, K. Business, Innovation, and Knowledge Ecosystems: How They Differ and How to Survive and Thrive within Them. Technol. Innov. Manag. Rev. 2015, 5, 17-24. [CrossRef]

16. Lundvall, B.-Å. (Ed.) National Systems of Innovation: Towards a Theory of Innovation and Interactive Learning; Pinter Publishers: London, UK; New York, NY, USA, 1992; p. 342.

17. Edquist, C. (Ed.) Systems of innovation approaches-Their emergence and characteristics. In Systems of Innovation: Technologies, Institutions and Organizations; Printer: London, UK, 1997; pp. 1-35.

18. Nelson, R.R. (Ed.) National Innovation Systems: A Comparative Analysis; Oxford University Press: New York NY, USA, 1993; p. 541.

19. Freeman, C. The 'National System of Innovation' in historical perspective. Camb. J. Econ. 1995, 19, 5-24. [CrossRef]

20. Cai, Y.; Liu, C. The roles of universities in fostering knowledge-intensive clusters in Chinese regional innovation systems. Sci. Public Policy 2015, 42, 15-29. [CrossRef]

21. Smorodinskaya, N.; Russell, M.; Katukov, D.; Still, K. Innovation Ecosystems vs. Innovation Systems in Terms of Collaboration and Co-creation of Value. In Proceedings of the Hawaii International Conference on System Sciences 2017, Hilton Waikoloa Vilage, HI, USA, 3-7 January 2017.

22. Carayannis, E.G.; Grigoroudis, E.; Campbell, D.F.J.; Meissner, D.; Stamati, D. The ecosystem as helix: An exploratory theory-building study of regional co-opetitive entrepreneurial ecosystems as Quadruple/Quintuple Helix Innovation Models. RED Manag. 2018, 48, 148-162. [CrossRef]

23. Cai, Y.; Ferrer, B.R.; Lastra, J.L.M. Building University-Industry Co-Innovation Networks in Transnational Innovation Ecosystems: Towards a Transdisciplinary Approach of Integrating Social Sciences and Artificial Intelligence. Sustainability 2019, 11, 4633. [CrossRef]

24. Lee, S.M.; Olson, D.L.; Trimi, S. Co-innovation: Convergenomics, collaboration, and co-creation for organizational values. Manag. Decis. 2012, 50, 817-831. [CrossRef]

25. Saragih, H.S.; Tan, J.D. Co-innovation: A review and conceptual framework. Int. J. Bus. Innov. Res. 2018, 17, 361-377. [CrossRef]

26. Leydesdorff, L. The Triple Helix, Quadruple Helix, ... , and an N-Tuple of Helices: Explanatory Models for Analyzing the Knowledge-Based Economy? J. Knowl. Econ. 2012, 3, 25-35. [CrossRef]

27. Carayannis, E.G.; Campbell, D.F.J. "Mode 3" and "Quadruple helix": Toward a 21st century fractal innovation ecosystem. Int. J. Technol. Manag. 2009, 46, 201-234. [CrossRef]

28. Scalia, M.; Barile, S.; Saviano, M.; Farioli, F. Governance for sustainability: A triple-helix model. Sustain. Sci. 2018, 13, 1235-1244. [CrossRef]

29. Scafarto, V.; Ricci, F.; Moscarini, F.; Corte, G.d. Analysing the concept of ecosystem: A systematic literature review. In Proceedings of the Knowledge ecosystems and growth, Matera, Italy, 5-9 June 2019.

30. Etzkowitz, H.; Leydesdorff, L. The Triple Helix-University-Industry-Government Relations: A Laboratory for Knowledge-Based Economic Development. EASST Rev. 1995, 14, 14-19. 
31. Sotarauta, M.; Heinonen, T.; Sorvisto, P.; Kolehmainen, J. Innovation Ecosystems, Competences and Leadership: Human Spare Parts and Venture Finance Ecosystems under Scrutiny; Tekes-The Finnish Funding Agency for Innovation: Helsinki, Finland, 2016.

32. Lundvall, B.-A.; Jurowetzki, R.; Lema, R. Combining the Global Value Chain and the Innovation System perspectives-A new agenda for Globelics research? In Proceedings of the 11th Asialics International Conference 2014, Daegu, Korea, 13-21 August 2014.

33. Necoechea-Mondragón, H.; Pineda-Domínguez, D.; Pérez-Reveles, L.; Soto-Flores, R. Critical factors for participation in global innovation networks. Empirical evidence from the Mexican nanotechnology sector. Technol. Forecast. Soc. Chang. 2017, 114, 293-312. [CrossRef]

34. Liu, J.; Chaminade, C.; Asheim, B. The Geography and Structure of Global Innovation Networks: A Knowledge Base Perspective. Eur. Plan. Stud. 2013, 21, 1456-1473. [CrossRef]

35. Barnard, H.; Chaminade, C. Global Innovation Networks: Towards a taxonomy. CIRCLE Work. Pap. 2011, $1-44$.

36. Pandey, N.; Desai, P.N. Exploring 'Global Innovation Networks' in Bio clusters: A Case of Genome Valley in Hyderabad, INDIA. J. Scientometr. Res. 2017, 6, 23-35. [CrossRef]

37. Wixted, B. Innovation System Frontiers: Cluster Networks and Global Value; Springer: Berlin/Heidelberg, Germany, 2009.

38. Krivtsov, V. Investigations of indirect relationships in ecology and environmental sciences: A review and the implications for comparative theoretical ecosystem analysis. Ecol. Model. 2004, 174, 37-54. [CrossRef]

39. Ritala, P.; Almpanopoulou, A. In defense of 'eco' in innovation ecosystem. Technovation 2017, 60, 39-42. [CrossRef]

40. Jackson, D. What Is an Innovation Ecosystem? National Science Foundation: Arlington, VA, USA, 2011.

41. Papaioannou, T.; Wield, D.; Chataway, J. Knowledge ecologies and ecosystems? An empirically grounded reflection on recent developments in innovation systems theory. In Proceedings of the 6th International Triple Helix Conference on University-Government-Industry Relations, Singapore, 16-17 May 2007.

42. Reichert, S. The Role of Universities in Regional Innovation Ecosystems; EUA: Brussels, Belgium, 2019.

43. Cai, Y.; Etzkowitz, H. Theorizing the Triple Helix model: Past, present, and future. Triple Helix 2020, in press.

44. Etzkowitz, H.; Webster, A.; Gebhardt, C.; Terra, B.R.C. The future of the university and the university of the future: Evolution of ivory tower to entrepreneurial paradigm. Res. Policy 2000, 29, 313-330. [CrossRef]

45. Pinheiro, R.; Langa, P.V.; Pausits, A. The institutionalization of universities' third mission: Introduction to the special issue. Eur. J. High. Educ. 2015, 5, 227-232. [CrossRef]

46. Chesbrough, H.W. Open Innovation: The New Imperative for Creating and Profiting from Technology; Harvard Business School; McGraw-Hill: Maidenhead, UK; Boston, MA, USA, 2003.

47. Armstrong, H.; Taylor, J. Regional Economics and Policy, 3rd ed.; Blackwell: Oxford, UK, 2000.

48. Cai, Y. Towards a socially responsible entrepreneurial university: Conceptual and analytical framework building. SPIRAL 2018, 2018, 1-4.

49. Heinzl, J.; Kor, A.-L.; Orange, G.; Kaufmann, H. Technology transfer model for Austrian higher education institutions. J. Technol. Transf. 2013, 38, 607-640. [CrossRef]

50. Moreton, S. Rethinking 'knowledge exchange': New approaches to collaborative work in the arts and humanities. Int. J. Cult. Policy 2016, 22, 100-115. [CrossRef]

51. Geuna, A.; Muscio, A. The Governance of University Knowledge Transfer: A Critical Review of the Literature. Minerva 2009, 47, 93-114. [CrossRef]

52. Blau, P.M. Exchange and Power in Social Life; J. Wiley: New York, NY, USA, 1964; p. 352.

53. Granovetter, M.S. The Strength of Weak Ties. Am. J. Sociol. 1973, 78, 1360-1380. [CrossRef]

54. Nkhata, A.B.; Breen, C.M.; Freimund, W.A. Resilient Social Relationships and Collaboration in the Management of Social-Ecological Systems. Ecol. Soc. 2008, 13, 2. [CrossRef]

55. Bidault, F. Managing Joint Innovation: How to Balance Trust and Control in Strategic Alliances; Palgrave Macmillan: Basingstoke, UK, 2012.

56. Abrahamson, E.; Rosenkopf, L. Social Network Effects on the Extent of Innovation Diffusion: A Computer Simulation. Organ. Sci. 1997, 8, 289-309. [CrossRef]

57. Capaldo, A. Network structure and innovation: The leveraging of a dual network as a distinctive relational capability. Strateg. Manag. J. 2007, 28, 585-608. [CrossRef] 
58. Michelfelder, I.; Kratzer, J. Why and How Combining Strong and Weak Ties within a Single Interorganizational R\&D Collaboration Outperforms Other Collaboration Structures. J. Prod. Innov. Manag. 2013, 30, 1159-1177. [CrossRef]

59. Barrie, J.; Zawdie, G.; João, E. Assessing the role of triple helix system intermediaries in nurturing an industrial biotechnology innovation network. J. Clean. Prod. 2019, 214, 209-223. [CrossRef]

60. Gretzinger, S.; Hinz, H.; Matiaske, W. Strong Ties, Weak Ties and the Management of Innovation: The Case of Danish and German SMEs. In New Developments in the Theory of Networks: Franchising, Alliances and Cooperatives; Tuunanen, M., Windsperger, J., Cliquet, G., Hendrikse, G., Eds.; Physica-Verlag HD: Berlin/Heidelberg, Germany, 2011; pp. 277-298. [CrossRef]

61. Levin, D.Z.; Cross, R. The Strength of Weak Ties You Can Trust: The Mediating Role of Trust in Effective Knowledge Transfer. Manag. Sci. 2004, 50, 1477-1490. [CrossRef]

62. Huang, J.; van den Brink, H.M.; Groot, W. College Education and Social Trust: An Evidence-Based Study on the Causal Mechanisms. Soc. Indic. Res. 2011, 104, 287-310. [CrossRef] [PubMed]

63. Cai, Y.; Liu, C. The Role of University as Institutional Entrepreneur in Regional Innovation System: Towards an Analytical Framework. In Examining the Role of Entrepreneurial Universities in Regional Development; Preto, M.T., Daniel, A., Teixeira, A., Eds.; IGI Global: Hershey, PA, USA, 2020; pp. 133-155. [CrossRef]

64. Battilana, J.; Leca, B.; Boxenbaum, E. How Actors Change Institutions: Towards a Theory of Institutional Entrepreneurship. Acad. Manag. Ann. 2009, 3, 65-107. [CrossRef]

65. Berger, P.L.; Luckmann, T. The Social Construction of Reality: A Treatise in the Sociology of Knowledge; Allen Lane: London, UK, 1967; p. 249.

66. Burns, T.R.; Flam, H. The Shaping of Social Organization: Social Rule System Theory with Applications; SAGE Publications: London, UK, 1987.

67. Scott, W.R. Institutions and Organizations, 2nd ed.; SAGE Publications: Thousand Oaks, CA, USA, 2001.

68. Cai, Y. Graduate employability: A conceptual framework for understanding employers' perceptions. High. Educ. 2013, 65, 457-469. [CrossRef]

69. Audretsch, D.B. From the entrepreneurial university to the university for the entrepreneurial society. J. Technol. Transf. 2014, 39, 313-321. [CrossRef]

70. Chandra, Y. Social Entrepreneurship as Institutional-Change Work: A Corpus Linguistics Analysis. J. Soc. Entrep. 2017, 8, 14-46. [CrossRef]

71. Haugh, H. New Strategies for a Sustainable Society: The Growing Contribution of Social Entrepreneurship. Bus. Ethics Q. 2007, 17, 743-749. [CrossRef]

72. Surie, G.; Groen, A. The importance of social entrepreneurship in national systems of innovation-An introduction. Technol. Forecast. Soc. Chang. 2017, 121, 181-183. [CrossRef]

73. Alzubi, Y. Knowledge transfer for sustainability: The role of knowledge enablers in the construction industries in Jordan. World J. Sci. Technol. Sustain. Dev. 2018, 15, 325-337. [CrossRef]

74. Cho, J.; Chan, K.S. Building Trust-Based Sustainable Networks. IEEE Technol. Soc. Mag. 2013, 32, 32-38. [CrossRef]

75. Nicholls, A. Social Entrepreneurship: New Models of Sustainable Social Change; OUP Oxford: Oxford, UK, 2008.

76. Ye, W.; Wang, Y. Exploring the Triple Helix Synergy in Chinese National System of Innovation. Sustainability 2019, 11, 6678. [CrossRef]

77. Gao, W.; Ding, X.; Chen, R.; Min, W. An Empirical Study of the Role of Higher Education in Building a Green Economy. Sustainability 2019, 11, 6823. [CrossRef]

78. Kumari, R.; Kwon, K.-S.; Lee, B.-H.; Choi, K. Co-Creation for Social Innovation in the Ecosystem Context: The Role of Higher Educational Institutions. Sustainability 2020, 12, 307. [CrossRef]

79. Bezanilla, M.J.; García-Olalla, A.; Paños-Castro, J.; Arruti, A. Developing the Entrepreneurial University: Factors of Influence. Sustainability 2020, 12, 842. [CrossRef]

80. Kangas, R.; Aarrevaara, T. Higher Education Institutions as Knowledge Brokers in Smart Specialisation. Sustainability 2020, 12, 3044. [CrossRef]

81. Iglesias-Sánchez, P.P.; Jambrino-Maldonado, C.; de las Heras-Pedrosa, C. Training Entrepreneurial Competences with Open Innovation Paradigm in Higher Education. Sustainability 2019, 11, 4689. [CrossRef]

82. Portuguez Castro, M.; Ross Scheede, C.; Gómez Zermeño, M.G. The Impact of Higher Education on Entrepreneurship and the Innovation Ecosystem: A Case Study in Mexico. Sustainability 2019, 11, 5597. [CrossRef] 
83. Wang, C.; Yang, J.; Cheng, Z.; Ni, C. Postgraduate Education of Board Members and R\&D Investment-Evidence from China. Sustainability 2019, 11, 6524.

84. Lattu, A.; Cai, Y. Tensions in the Sustainability of Higher Education-The Case of Finnish Universities. Sustainability 2020, 12, 1941. [CrossRef]

85. Cruz-Amarán, D.; Guerrero, M.; Hernández-Ruiz, A.D. Changing Times at Cuban Universities: Looking into the Transition Towards a Social, Entrepreneurial and Innovative Organization. Sustainability 2020, 12, 2536. [CrossRef]

86. Ma, J. Developing Joint R\&D Institutes between Chinese Universities and International Enterprises in China's Innovation System: A Case at Tsinghua University. Sustainability 2019, 11, 7133.

87. Cai, Y. Implementing the Triple Helix model in a non-Western context: An institutional logics perspective. Triple Helix 2014, 1, 1-20. [CrossRef]

88. Cai, Y. What contextual factors shape 'innovation in innovation'? Integration of insights from the Triple Helix and the institutional logics perspective. Soc. Sci. Inf. 2015, 54, 299-326. [CrossRef]

89. Chen, Q.; Li, Y. Mobility, Knowledge Transfer, and Innovation: An Empirical Study on Returned Chinese Academics at Two Research Universities. Sustainability 2019, 11, 6454. [CrossRef]

90. Liu, J.; Yin, Z.; Lyu, W.; Lin, S. Does Money Accelerate Faculty Mobility? Survey Findings from 11 Research Universities in China. Sustainability 2019, 11, 6925. [CrossRef]

91. Akhtar, N.; Pratt, C.B.; Hu, Y. Sustainability of the Belt and Road Initiative: An Integrated, Conceptual Framework for Instructional Communication in China's Universities. Sustainability 2019, 11, 6789. [CrossRef]

92. Li, H. How to Retain Global Talent? Economic and Social Integration of Chinese students in Finland. Sustainability 2020, 12, 4161. [CrossRef]

(C) 2020 by the authors. Licensee MDPI, Basel, Switzerland. This article is an open access article distributed under the terms and conditions of the Creative Commons Attribution (CC BY) license (http://creativecommons.org/licenses/by/4.0/). 